\title{
MANAGING LOCAL PUBLIC DEBT IN TRANSITION COUNTRIES: AN ISSUE OF SELF-CONTROL?
}

\author{
Krisztina Tóth \\ Bernard Dafflon* \\ Paper prepared for the $14^{\text {th }}$ Annual Conference of the Network of Institutions and Schools of \\ Public Administration in Central and Eastern Europe (NISPAcee) \\ Ljubljana, May 11-13, 2006
}

First draft (11 April 2006)

\begin{abstract}
Most of the literature on managing local public debt in Central and Eastern Europe is concerned either with the existing institutional restrictions on borrowing, or with sanctions against excessive debt. One common feature of these approaches is that they place the role and responsibility of the central state in the forefront while considering local government performance as a dependent variable. The present study drops the traditional analytical perspective of budget discipline and focuses instead on the budget responsibility (or self-control) of local governments. It argues that compliance with the legal norms and a favourable rating at the bank are necessary but not sufficient conditions for a municipality to incur debt. Success in the overall financial management requires a more proactive attitude in which local policymakers adjust their investment policy to the actual debt capacity of the local government, assessing the short, medium and long-term costs and benefits of each investment project.
\end{abstract}

Keywords: public debt, borrowing, local government, local public finance, capital investment, hard budget constraint, transition economies, Central and Eastern Europe.

JEL Classification: H72, H74, H77, H82

\footnotetext{
* Dr. Bernard Dafflon is a senior professor in public finance at the University of Fribourg Switzerland. Krisztina Tóth is a research assistant and Ph.D. candidate under the direction of professor Dafflon. Mailing address: University of Fribourg Switzerland, Department of Economics, Chair of Public Finance, Bd. de Pérolles 90, CH-1700 Fribourg, Switzerland. E-mail: bernard.dafflon@unifr.ch; krisztina.toth@unifr.ch. Internet: http://www.unifr.ch/finpub. This is a work in progress. Please do not cite. Comments are welcome.
} 


\section{Introduction}

The overwhelming majority of the existing literature on managing local public debt in transition countries is concerned either with the existing institutional restrictions on borrowing, or with sanctions against excessive debt. Country studies discuss at great length the development of the regulatory framework of local borrowing, the instruments of administrative control, the balanced budget rules, the accounting and reporting requirements, the collaterals, and the role of credit rating agencies, in order to draw conclusions on the progress in public debt management policies. Others analyse the practice of bail-out grants or forced administrative procedures aiming at the correction of local government budgets in which deficit and debt is accumulated.

While the channelling of local government behaviour by the centre is clearly indispensable for the development of sound debt management practices at the local level, the analyses of such disciplinary measures invariably place the role and responsibility of the central state in the forefront while considering local government performance as a dependent variable.

The present study drops the traditional analytical perspective of budget discipline and focuses instead on the budget responsibility (or self-control) of local governments. Our main message is that compliance with the legal norms and a favourable rating at the bank are necessary but not sufficient conditions for a municipality to incur debt. Success in the overall financial management requires a more proactive attitude. This appears to be confirmed by a few regrettable cases of municipal insolvency throughout Central and Eastern Europe (CEE) in the past ten years which exhibit a huge complexity of factors leading to fiscal crisis. While some of these factors are related to wrong incentives provided by the institutional environment (unfunded mandates driving municipalities to borrow, central government grants distorting local investment choices etc.), much of the debt problem has to do with the poor practices in planning and managing local investment programmes. Typical management errors include the nonexistence or poor quality of medium- and long-term investment plans, oversized investment projects, the resistance against co-operation with other municipalities for financing and operating the asset, the voluntary introduction of new spending competences beyond the real financial capacity, or the ignorance about future (operating and maintenance) costs related to the investment. Wrong incentives emerge also when the issue of budget balance is viewed solely from the perspectives of liability management and accountability, without due attention to the fact that the local budget is first and foremost a mirror of the public policies (expenditures and revenues) pursued by the local government.

Following this introduction, in Section 2 we present the current environment of financing local investments in CEE and the equity challenge related to financing from current revenues. Starting with the hypothesis that investment funding should better be based on the pay-as-you-use (debt) than on the pay-as-you-go (current revenues) principle, Section 3 outlines the strengths and limits of the traditional regulatory framework in CEE (rules, sanctions, and direct control) and explains the case for budget responsibility as a substitute for budget discipline. It also presents an inventory of common management errors that local policymakers commit in connection with local infrastructure investments. Section 4 provides guidelines on how to transform budget responsibility from a theoretical principle into real-life practice. Section 5 concludes. 


\section{Financing Local Infrastructure in Central and Eastern Europe}

\subsection{Some Facts and Figures}

Comparative statistics on local public debt in Central and Eastern Europe (CEE) are fairly poor. Nevertheless, the available data suggest that the average level of indebtedness of subnational governments in Central and Eastern Europe remains well below that of other European countries. While the European Union (EU) average is already quite modest, local government debt constituting around five per cent of GDP (DEXIA 2002), it seldom reaches two per cent in the new member states whose economic performance is otherwise comparable to the middle-income countries in Western Europe. Transition countries outside the EU (in the Balkans and the former Soviet Union) show even lower ratios (Swianiewicz 2004: 399). ${ }^{1}$

Recent publications on comparative public finance in CEE (Högye 2002; Swianiewicz 2004a) have revealed that the reluctance of decentralised government units has not only to do with economic development but also with intergovernmental fiscal institutions and, surprisingly, with cultural attitudes of politicians and voters. The main reasons for the low level of subnational debt in CEE have been identified as follows:

- lack of technical and administrative capacity to manage debt;

- poor predictability of current revenue flows (due to macroeconomic and institutional reasons);

- gains from privatisation, intergovernmental grants as substitutes for debt finance;

- cultural aversion against indebtedness (debt is a sign of financial instability; debt is a risky form of financing; debt places an unfair burden on future generations);

- inhibiting rules for borrowing and debt;

- disparities in the local tax base and valuable property, reducing the chances for small municipalities to borrow;

- lack of a mature financial market;

- high interest rates due to inflation;

- minor role of local governments in public sector investments.

While none of the CEE countries has to struggle with the totality of these problems, obstacles to debt financing are often cumulated and affect the most severely those local governments with a relatively low financial and administrative capacity. Consequently, even in those domains of local government activity where debt would be an appropriate (or the most appropriate) means of financing, local authorities in transition countries prefer using (i) conditional transfers and targeted investment grants from the central government budget, (ii) proceeds from privatisation of assets, or (iii) own-source revenues (taxes, user charges). Grants-in-aid from international organisations (such as the EU) and public-private partnerships play a minor but not negligible role in financing local government.

\footnotetext{
${ }^{1}$ Debt accumulated by the off-budget entities of local governments (such as public works, enterprises partially or entirely owned by the municipality, or contracted providers for which the municipality operates as a guarantor) is usually not reflected in the CEE statistics. Alone in Hungary there are about 1600 such companies in the service of 3200 local governments, and their role in infrastructure development is almost as important as that of the local government (Balás and Hegedüs 2004).
} 
Nevertheless, in some countries of the CEE region the use of debt by local governments has substantially increased over the last decade. Though the volume of loans and bonds is still very small in absolute terms, the trend is remarkable as borrowing means a huge qualitative progress in the practice of financing local service responsibilities (Wetzel 2001: 40). There is a variety of factors behind the increase of local government debt levels. Particularly Hungary, Poland, the Czech Republic, Slovakia, and Estonia, have witnessed a rapid development in the debt management skills of their subnational authorities (much assistance has been received from bilateral and international donor organisations, too) and the strengthening of local economies, which was crucial for developing a solid basis of local own-source revenues. Also, the reserves from one-shot privatisation revenues and the remaining assets on sale are now gradually depleted, even though this trend is largely compensated by conditional grants that have even become increasingly important in the light of an increased demand for infrastructure investments in connection with the EU membership. The improvement in the overall macroeconomic situation has started to bring down interest rates in these countries and financial markets finally start to open up for the most creditworthy municipalities. Nevertheless, the traditional aversion against indebtedness and the poor access of the smallest and weakest local governments to borrowing are persisting problems.

\subsection{Financing from Debt vs. Current Revenues: A Question of Equity}

While the worst possible way of using local government debt is probably for covering the operational deficit (Buchanan and Wagner 1977, Dafflon 1998: 71), debt as a financing instrument can and should have a primordial role in another section of the local public budget, notably in the investment accounts. For sure, debt is not the only way of covering the costs of renewal and development of local government infrastructure. Intergovernmental or foreign grants-in-aid, local taxes and user charges and revenues from asset sales may equally ensure the necessary funding for an investment project (traditionally called pay-as-you-go finance), though they alone are not likely to be sufficient to finance an entire investment programme of a year. Particularly with regard to the gigantic infrastructure need of CEE countries related to (i) the renewal of depleted assets from the soviet period, (ii) the compliance with EU norms, and (iii) the push for "prestige investments" before local elections (Balás and Hegedüs 2004), it is an illusion to expect that current revenues will be sufficient to provide a durable basis for investment policy.

There is an even more important argument that is independent from the availability of current revenues (which is a question of economic development) and has a massive influence on the attitude of local decision-makers towards funding public service responsibilities in general. If we accept that real investment means the purchase or production of a capital good that has a long life and the benefits from which are spread over several years, then funding investment from the current operational budget of the local government is necessarily suboptimal as it raises a problem of inter-generational equity. In Musgrave's words (Musgrave 1963: 135), "if the government incurs outlays, the benefits from which are spread over a future period, it is unfair to ask the initial generation to sustain the whole cost. Rather, 'prudence' requires that finance be based on a pay as you use basis, each generation contributing a cost share commensurate with its own share in the benefit stream." 
Since the birth of Musgrave's theorem, most of the public finance textbooks have introduced a section comparing the pro and contra arguments of pay-as-you-go and pay-as-you-use finance (see e.g. Coombs and Jenkins 1994: 182 ff). These arguments are certainly not unknown to the local decision-makers in CEE transition countries. They have also been reiterated most recently by Paweł Swianiewicz (2004b: 5 ff.) in a volume explicitly directed to the attention of the CEE research community on public finance, so that it is unnecessary to recall them here again. Yet, as Swianiewicz observes towards the end of the volume, only few local governments in the CEE region have as yet realised the meaning of the intergenerational equity argument. Most local authorities continue to use debt as a complementary financing instrument in case the current revenues are too short to cover the costs of investment projects. Even some academics express their concern about the fact that an increasing share of investments need to be financed from debt (and transfers) instead of own-source revenues (e. g. Blažek et al. 2003), though these concerns could also derive from the fact that it is difficult to ensure a smooth debt service as long as both own-source revenues and intergovernmental transfers are subject to yearly fluctuations. In any case, local governments in CEE show a clear preference towards pay-as-you-go finance, notwithstanding the number of difficulties which are, for the different parts of the current budget, the following:

- Conditional grants and targeted investment subsidies: (i) poor predictability (see above); (ii) grants are "free of charge", thus reducing the accountability of local governments and inducing a substitution effect towards grant-financed capital projects; (iii) local investment priorities are largely determined by the availability of grants; (iv) in some countries investment grants cannot be used for ongoing projects, which incites local governments to embark on more and more new projects with little thought about future financing.

- Intergovernmental transfers and general grants: (i) the rules of revenue sharing are subject to frequent modifications; (ii) local governments depend heavily on the national tax office for timely information to make accurate revenue forecasts; (iii) transfers are subject to annual changes in the budget.

- Revenues from privatisation: (i) assets are running out, reducing the potential for future revenue raising (user charges; leasing fees; assets as collaterals for loans); (ii) privatisation yields one-shot revenues and allows rarely to cover future operating costs related to the investment project.

- Local taxes and fees: (i) local governments are reluctant to raise own revenues, and/or the taxable basis is to a large part "occupied" by the central tax authorities; (ii) local governments seldom take into account the revenue potential generated by economic growth (enlarging the local tax base); (iii) the interregional distribution of tax base is unequal; small jurisdictions have little revenue from this source.

- Foreign grants-in-aid (e.g. EU funds): (i) strict co-financing requirements; (ii) ex post reimbursement; (iii) need for strong project management capacity.

- Public-private partnerships are efficient in funding individual infrastructure projects but cannot alone ensure the financial basis of the entire capital expenditure policy of a local government. 
It follows clearly from the above explanations that the circumstances of financing local capital expenditures in Central and Eastern Europe are still far from optimal, and this is true for pay-as-you-go as well as for pay-as-you-use finance. Nevertheless, the intergenerational equity principle and the fact that current revenue flows are simply insufficient to finance the infrastructure need in these countries, turn the balance in favour of the latter approach. It seems that this recognition has not yet spread over from the theory to the practice of managing local public finances in the region.

\section{Focus on Budget Discipline: Value and Limitations}

\subsection{Rules and sanctions}

If we accept that debt is the most appropriate instrument for financing local public investments, then our next step is to find out, not how local authorities can obtain access to debt financing, nor which borrowing and debt rules they must obey to (these issues have been the subject of previous studies, see e.g. Wetzel 2001, Swianiewicz 2004a), but how, through which mechanisms of internal financial management they can comply with these rules.

In the past fifteen years, in all countries of Central and Eastern Europe subnational governments have been granted full or limited access to borrowing. Institutional rules on borrowing and debt have been laid down, including balanced budget rules (either for the current account - "golden rule" -, or for the overall budget), debt ceilings, restrictions on borrowing from overseas and/or from the central bank. Also, central legislatives and executives are working hard in order to create the necessary framework in which the financial market can build up trust in local governments as potential borrowers. In a few countries such as Hungary, specific legal procedures have been elaborated in order to deal with cases of excessive indebtedness and insolvency of local public entities. In other countries, the central government counts on commercial lenders and credit rating agencies to enforce borrowing discipline among local authorities. Yet other governments have introduced direct administrative control on individual borrowing operations.

The description of these rules and sanctions constitute today the thrust of several academic studies on local borrowing and debt in CEE. Major inspiration to this kind of work was provided by Ter-Minassian and Craig (1997) who give a comparative overview on the control of subnational borrowing practices in 53 countries worldwide and distinguish four models on this basis: reliance on market discipline, co-operative approach, rules-based approaches and direct (administrative) control. Another significant input to the CEE research in this policy area was given by Dafflon (2002) whose author team provides a similar but more exhaustive analysis for ten selected West European countries.

Out of the four models defined by Ter-Minassian and Craig, rules-based control and direct control are the most frequently used in the CEE region. Examples of rules-based control are the upper limits on the total annual amount of debt service in Albania, Estonia, Hungary, Poland and Slovakia, ceilings on the amount of overall debt in Estonia, Poland, Romania and Slovakia (Gurraj et al. 2002, Sootla et al. 2002, Balás and Hegedüs 2004; Kopańska and Levitas 2004, Kling and Nižňanský 2004, Ghinea et al. 2004) or the limits on the annual amount of short-term loans 
in Romania and Bulgaria (Popa et al. 2002, Tchavdarova et al. 2002). Instruments of direct control can be found in Estonia where municipalities must ask the Ministry of Finance for an ex post approval on each borrowing operation (Sootla et al. 2002), in Slovakia where a similar approval is needed ex ante (Kling and Nižňanský 2004), and in Poland where the borrowing rights of local governments are restricted as soon as the consolidated public debt reaches 5 per cent of the national GDP (Filas et al. 2002). Many countries apply a combination of rules-based control and direct control, sometimes completed with a reliance on market discipline (depending on the maturity of financial markets) and sanctions for the case of non-compliance. A classical example of sanctions is the so-called debt adjustment (or bankruptcy) procedure for local governments in Hungary in case of default on debt or other obligations (Jókay et al. 2004). ${ }^{2}$

Although a minimum of regulation is necessary in order to prevent massive defaults of subnational units with serious repercussions on the national economy, both rules-based control and administrative control have their limitations. Rules-based approaches generally lack flexibility and incite local governments to get around the rules, as has occurred in a couple of countries according to the reports by Ter-Minassian and Craig (1997) and Ratts $\varnothing$ (2002). The instruments of administrative (direct, preventive) control make subnational governments excessively dependent on the support by central authorities and induce moral hazard problems (Rossi and Dafflon 2002: $36 \mathrm{f}$.).

Throughout the entire CEE region the different national "policy mix" solutions have effectively laid down the foundations of prudent subnational borrowing (Wetzel 2001: 38). In our view, however, and from the perspective of the borrowing subnational authority, rules and sanctions are necessary but not sufficient conditions of a sound debt management. By their very nature, rules are ex ante restrictions that subnational governments must respect before taking any decision on borrowing, whereas sanctions are ex post reactions to situations of excessive indebtedness. The centre's influence on local government behaviour is certainly indispensable for the development of sound debt management practices at subnational levels. However, the existing CEE literature which underlines the importance of budget discipline (the compliance with rules and sanctions) places the centre of gravity on the national government and treats municipal performance as a simple dependent variable. While rules and sanctions may be efficient in preventing subnational governments from excessive borrowing and thus in protecting the national government from fiscal imbalances deriving from the local public sector, they cannot "tell" local decision-makers what to do in order to fully benefit from the advantages of debt finance without running the risk of insolvency.

On the basis of these arguments we consider budget discipline as a negative approach to obtaining a balanced budget at subnational levels. The corresponding positive approach is then viewing the balanced budget as a result of a prudent and proactive budget policy through which local governments adjust their investment policy to their real fiscal capacity and assess costs and benefits of each capital programmes in advance, in order to avoid excessive debt. We may call this approach budget responsibility (or self-discipline).

Shifting the emphasis from budget discipline towards budget responsibility by no means implies that a regulatory framework is unnecessary or that credit rating agencies do not count for borrowers' discipline. Rather, sound financial management requires that similar rules and sanctions be established internally as well, upon the rational

\footnotetext{
${ }^{2}$ For more details on the regulatory frameworks in individual countries, see Wetzel (2001), Högye (2002) and Swianiewicz (2004a).
} 
deliberation and voluntary decision of subnational governments. One remarkable difference between local financial management practices in unitary and federal systems is the fact that, in unitary countries, rules and administrative procedures concerning borrowing and debt are imposed exclusively by the central government, whereas in federal systems central regulations are kept at a minimum and much room is left to regional and local governments to decide whether they wish to introduce such instruments voluntarily in their own legislation or not.

Obviously, leaving the decision about control mechanisms to the discretion of subnational governments can work only if the latter have a strong sense of responsibility for the welfare of their constituency and if the economy is characterised by hard budget constraints (that is, if bail-out by the central government is ruled out). What we wish to put forward here, however, is not so much a switch from external (top-down) to internal rules as rather the introduction of internal rules as supplement to external regulations.

\subsection{Some Typical Management Errors in CEE and the Case for an Effective "Golden Rule"}

Even though decentralised authorities throughout Central and Eastern Europe generally respect the relevant national regulatory framework for subnational borrowing and debt and cases of insolvency are quite rare, this does not imply that the budget management policies they pursue are absolutely sound. This is mainly due to the lack of skills and experience with capital programmes and capital budgeting. Nevertheless, as recent country studies show, imprudent fiscal behaviour can be observed even in rich urban municipalities and powerful regions that have high fiscal capacity, presumably strong management skills and therefore an easy access to borrowing.

Instead of recalling the generalised and slightly stereotyped findings about the lack of planning and monitoring skills, poor feasibility studies and project evaluations, outdated information systems, ill-designed accounting policies and other deficiencies at the subnational level, Figure 1 highlights some of the management errors that commonly occur in local governments of transition countries in connection with investments.

It is important to note in advance that not all these errors occur systematically in all of the countries. Some errors may be more typical of a few countries of the region, while others may occur more frequently in other countries.

The errors can be divided in two groups. Those related to the economic management of investment programmes are listed vertically in the boxes along the left-hand margin of the figure. The dark boxes arranged horizontally along the bottom margin show errors in the political (or policy) management. The ultimate consequences and risks deriving from these various defaults are indicated on the right-hand side of the figure.

Typical errors in the economic management of investments include the poor assessment of project feasibility and the continued resistance against interjurisdictional co-operation. Particularly small rural municipalities show substantial deficits in these areas. According to a report by Jókay et al. (2004), all of the local governments in Hungary that went bankrupt in the first five years following the adoption of the Law on Municipal Debt Adjustment (no. XXV of 1996) were small rural villages engaged in large-scale infrastructure programmes (gas supply, wastewater pipelines) that were both technically and financially unrealistic. The lack of professional expertise and planning capacity is one possible reason for this fatal error. However, these local councils can also be made responsible for ignoring the 
alternative solution, notably the realisation of the investment programme in co-operation with the surrounding municipalities. A co-operation agreement would have allowed these municipalities to hire a planning expert and save costs in the project implementation through the realisation of scale economies.

\section{Figure 1}

\section{Typical errors in investment management in CEE and their consequences}

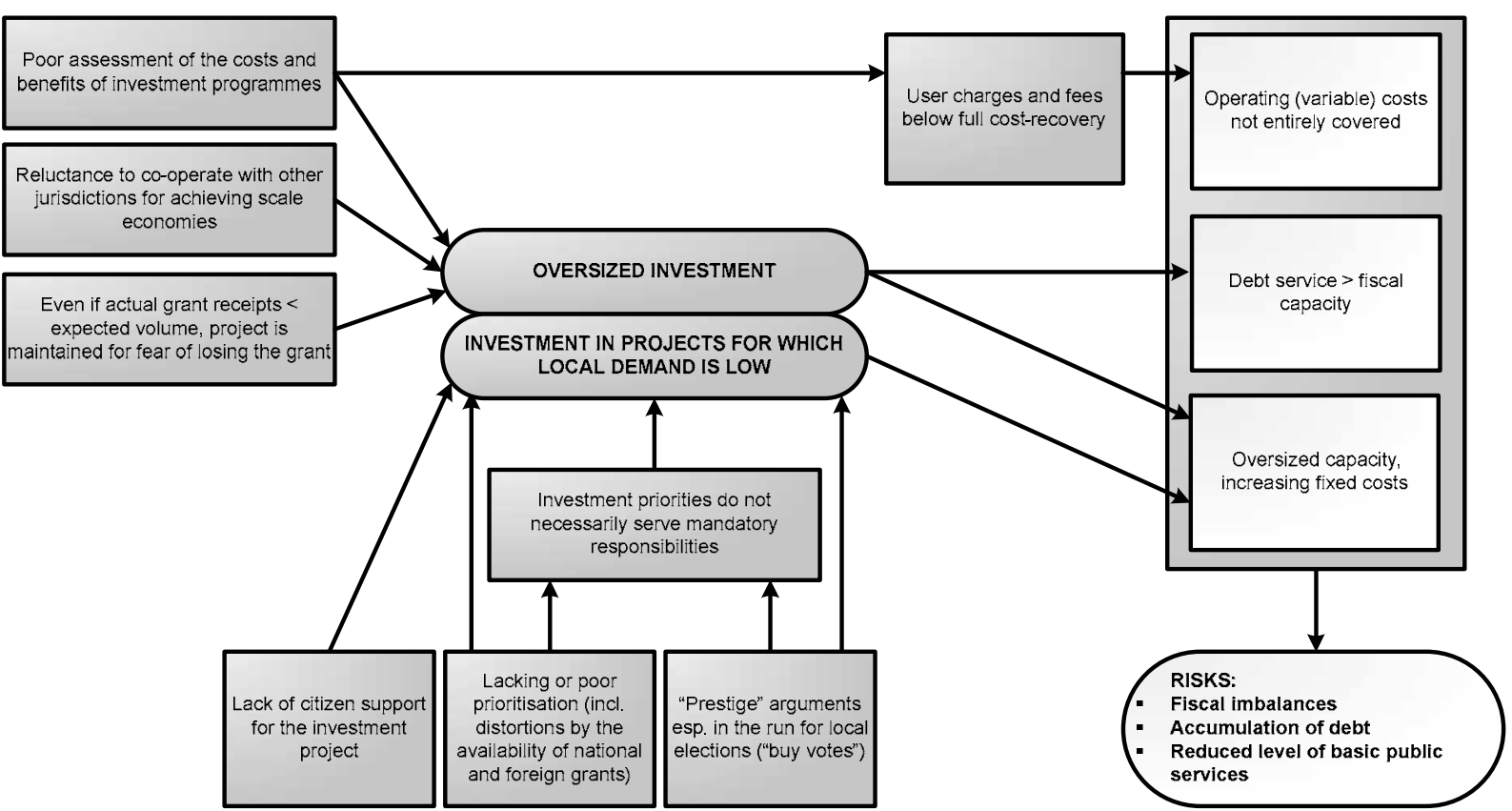

Source: the authors, based on country studies in Högye (2002), Swianiewicz (2004) and Jókay et al. (2004)

A corollary of the poor assessment of costs and benefits is that local governments do not fully exploit the potential of consumption-related revenue sources such as user charges and fees. As is reported from several countries of the region (e. g. Filas et al. 2002), such levies tend to remain below the level of full cost-recovery and local government treasurers prefer the simpler solution of financing the maintenance and the operation of the asset from the general revenues of the community.

Finally, a fourth error of economic management is the local governments' obstinacy with regard to the implementation of programmes for which the received co-funding (grants-in-aid, state loans) falls short of the expected levels. Local governments are reluctant to give up such investment programmes, for fear of losing the financial support they had obtained in a long battle (and through competing against other local governments) from the central budget or from foreign aid funds. They prefer maintaining their plans and filling the budget gap with own-source revenues, bonds or bank credits, thereby placing their liquidity position under pressure.

Errors in the economic management most often lead to oversized capital programmes, that is, programmes that bear no relationship with the financial capacity of the jurisdiction. 
Errors in the political management of investment programmes have mainly to do with priorities. First, it is important that the majority of citizens support the project and are also willing to use the facilities once they are built (a warning example is the case of Dolná Lehota in Slovakia, see Kling and Nižňanský 2004). Second, investment priorities should be clearly defined and be the result of a democratic process. As we mentioned earlier, local investment policy in CEE is mainly driven by the availability of central government transfers and international funds. In the current unstable situation of investment financing, subnational governments feel that they have to participate in the investment grant programmes even if the priorities defined in these programmes do not entirely match the priorities of the local community. Resistance against this kind of distortion in the investment policy is essential but difficult as long as grants constitute the most important source of capital development (Blažek et al. 2003, Kopányi et al. 2004).

A third error in political management is pursuing prestige motives in the investment policy. This can occur any time when the purpose of the local politician is to attract new businesses and taxpayers to the jurisdiction, but it is particularly common in the run-up to local elections.

Failures in the political management normally lead to investment programmes for which the local demand is low. Especially lacking or poor prioritisation (including the distortions induced by grant programmes) and the "buy votes" behaviour of local politicians may result in capital programmes that serve voluntary expenditure functions (e. g. road construction, industrial parks), taking away important resources from the infrastructure development in the areas of mandatory responsibility such as schools, hospitals or environmental protection (Balás and Hegedüs 2004).

The immediate effects of all these management errors are at least threefold, namely:

- The overinvestment leads to debt levels that are far too high compared to the financial capacity of the local government;

- New assets are rapidly depleted and/or cannot be fully exploited during their useful life because the costs of maintenance and operation were not included in the investment budget from the beginning;

- The created excess capacity unnecessarily increases the overhead costs.

If the local government makes no correction in response to these management problems, the situation may escalate and lead to persistent fiscal imbalances, the accumulation of the debt level, or a reduction in the quantity and the quality of local public services.

It is important to note, however, that these errors are often rational responses to the incentives provided by either the general macroeconomic situation or (and most often) by particular institutions of intergovernmental finance. The typical errors from the part of the central government and/or national legislation may include the following:

- The intergovernmental grant flows are subject to annual modifications through the budget law, making multi-year investment budgeting and the planning of maintenance and operation of the asset nearly impossible;

- National and international grant programmes encourage municipalities to build capacities that they cannot afford to operate in the long run; 
- The ability to cover the future costs of maintenance and operation of the asset is not a formal condition of eligibility for investment grants (e. g. in Hungary, see Kopányi et al. 2004);

- $\quad$ the public sector continues to pursue cash-based accounting and budgeting which does not allow to spread out investment costs over the entire lifetime of the asset;

- In most CEE countries, assets are recorded at their net book value (acquisition costs minus accumulated depreciation) that can be very different from their actual market value, thus distorting the asset management and the calculation of user charges;

- $\quad$ There are no established depreciation rates for the different asset categories (e. g. in Croatia, see Ott and Bajo 2002).

In order to prevent serious fiscal imbalances and excessive debt levels at subnational levels, the classical theory of fiscal federalism and decentralisation has traditionally promoted the case for "golden rules", that is, rules that oblige the local government to keep its current account in equilibrium (either on a yearly basis or over the business cycle) and allow the accumulation of deficit only on the capital account.

Interestingly, while "golden rules" constitute the backbone of subnational debt control in several West European countries and are reportedly an effective instrument for controlling debt, they are either non-existent or dysfunctional throughout the entire CEE region. In Bulgaria, Croatia, the Czech Republic, Hungary, Poland and Romania, such rules do not exist, borrowing is allowed for both operational and investment purposes. In Albania and Estonia, the right of local borrowing is limited to investment purposes, however, subnational authorities are not required to formally separate their capital budget from the operating budget (though they are encouraged to do so). Slovakia (since 2001) is the only country in the region where the operating and capital budgets are formally separated and an equilibrium is required only for the former. However, "in exceptional situations where the autonomy of a municipality is endangered" (whatever this may mean), the local council can take funds from the capital budget to finance current expenditures up to 25 per cent of the budgeted revenues (Kling and Nižňanský 2004: 187). As Swianiewicz (2004c: 394) notes, so far there have been few cases in CEE where local governments abused this situation by financing operating expenditures from debt, yet this might become a problem in the future, especially if the financial resources for the daily operation of local government services remain tight.

One important precondition to an effective implementation of the "golden rule" is the adequate definition of key terms such as "investment" (i. e. what should appear on the capital account?), "debt service", or "amortisation", as well as the separation of current and capital budgets. It must be noted, however, that both the "golden rule" and the separation of the budgets have their opponents in the current debate on fiscal federalism, their main argument being the inflexibility of the rule with regard to cyclical downturns (for an overview of this debate, see Novaresi 2001, or Rossi and Dafflon 2002).

Even if the national legislation does not impose a "golden rule" nor a separation of current and capital budgets, nothing impedes local governments to adopt such measures in their internal financial management organisation upon a voluntary basis. This is a common practice in mature federations where subnational entities have not only a fairly broad autonomy but also the full responsibility for their finances. The jury is still out on the question whether top- 
down rules and self-imposed rules bring similar results in terms of the overall fiscal balance of subnational governments, and what specific motives (if any) may compel a local government to adopt legally binding rules on the local budget process and investment funding (see Pujol 2000, Novaresi 2001). In any case, the choice between rules and discretion in deficit and debt control is not free from trade-offs. As Roubini (1995: 6) points out, rigid fiscal rules do not allow policymakers to run deficits either for political motives or during economic recession. Conversely, fiscal discretion may result in excessive deficits if there is a political bias in fiscal policy, but it provides the flexibility of running deficits during periods of economic downturn.

\section{From Budget Discipline to Budget Responsibility}

\subsection{Nine Key Questions for a Positive Approach to Local Debt Management}

What we attempt to propose with the present draft paper is this: the formal compliance with top-down fiscal rules and the positive signals received from the financial market should not be regarded as an automatic and immediate authorisation to new investments. It is wrong to think "As long as we can enjoy such an excellent credit rating, we will always have access to credits." The logic should be the other way round: "We need this particular investment, thus we might need to take a loan from the market. But do we have the capacity on the medium (or long) term to repay it?" It is equally wrong to say: "We fully comply with the debt (or debt service) limits prescribed by the law, thus we can embark on the planned capital project." We should better consider: "Can we afford this project in the present financial situation of the municipality? If yes, how are we going to finance it? What are the implications of the various funding alternatives (local own-source revenues, intergovernmental grants, debt instruments, or a combination of these) in economic and political terms?"

These fairly unpretentious examples are supposed to illustrate that, for the overall financial "health" of a decentralised government unit, budget responsibility matters even more than budget discipline. As soon as one is willing to accept this hypothesis, the budget management practices of the local government need to be examined upon whether they promote or inhibit local policymakers in assuming budget responsibility. In Table 1 we propose nine key questions that might assist this process. In the recognition that some of the components of budget responsibility cannot be respected without the existence of a proper legal framework, we have added some relevant recommendations for the central government as well.

\subsection{The Local Government Model of Sustainable Investment Finance}

In this last section of the paper we attempt to provide a graphic model of the sound investment management of local governments.

On the basis of the experience derived from the ten case studies in Dafflon (2002), we can develop the foundations of an analytical framework that allies the "golden rule" and the distinction between current and capital accounts with pay-as-you-use finance. The general formula looks as follows: 
Table 1 Nine key questions for checking budget responsibility

\begin{tabular}{|c|c|c|}
\hline \# & Questions & $\begin{array}{l}\text { Implications for subnational governments (SNG) / } \\
\text { central government }(\mathrm{CG}) \text { / national legislation }\end{array}$ \\
\hline 1 & \multicolumn{2}{|l|}{ Budget discipline or budget responsibility? } \\
\hline & $\begin{array}{l}\text { - Does your local government council (in co-operation with } \\
\text { the financial department or the financial manager) carry } \\
\text { out any kind of a self-assessment before each investment } \\
\text { decision? } \\
\text { - If yes, what issues are taken into consideration during } \\
\text { these self-assessments? }\end{array}$ & $\begin{array}{l}\text { The CG and international donors should assist subnational } \\
\text { governments in acquiring the necessary skills for cost- } \\
\text { benefit-analysis and feasibility assessments. }\end{array}$ \\
\hline 2 & \multicolumn{2}{|l|}{ Is the current budget distinct from the capital budget? } \\
\hline & $\begin{array}{l}\text { - Is borrowing limited to investment or also allowed to } \\
\text { cover the operational deficit? } \\
\text { - If the separation of the current and the capital budget is } \\
\text { encouraged (or at least not a priori ruled out) by the law, } \\
\text { has your local council already done it or is planning to do } \\
\text { so? }\end{array}$ & $\begin{array}{l}\text { The law should prescribe, encourage, or at least tolerate the } \\
\text { separation of local current budgets from the investment } \\
\text { budgets, for a better transparency of the fiscal situation of } \\
\text { the community, with special regard to its debt service } \\
\text { capacity. The term "investment" should be defined at the } \\
\text { national level. }\end{array}$ \\
\hline 3 & \multicolumn{2}{|l|}{ How is the capital budget decided? } \\
\hline & $\begin{array}{l}\text { Is there any local discretion in investment decision- } \\
\text { making? } \\
\text { - Does the decision concern only the entire capital budget } \\
\text { or also the individual items of the capital budget? } \\
\text { - Is it necessary to elaborate a detailed plan for each } \\
\text { investment project and discuss it in the local council? }\end{array}$ & $\begin{array}{l}\text { The sense of budget responsibility requires the local council } \\
\text { to take separate decisions about the individual investment } \\
\text { plans, their order of priority, and the yearly capital budget } \\
\text { which also includes the funding need of several running } \\
\text { projects that are in different stages of implementation. }\end{array}$ \\
\hline 4 & \multicolumn{2}{|l|}{ Is a separate vote needed for... } \\
\hline & $\begin{array}{l}\text { - ...the current budget? } \\
\text { - ...taxes in the current budget? } \\
\text { - ...particular items of the capital budget? } \\
\text { - ...the total capital budget? } \\
\text { - ...other items in the budget? }\end{array}$ & $\begin{array}{l}\text { If votes are made separately, SNG should make sure that no } \\
\text { cost or revenue items are left out of the calculation. Ignoring } \\
\text { future operating costs or potential user charges is a common } \\
\text { error. }\end{array}$ \\
\hline 5 & \multicolumn{2}{|c|}{ Is a rule of balance imposed on the current (or the entire) budget? } \\
\hline & $\begin{array}{l}\text { - Which level of government sets the rule? } \\
\text { - What are the reasons for or against such a rule? } \\
\text { - on the actual account? } \\
\text { - Does it allow the annual deficit to be carried forward to } \\
\text { the following fiscal year? If yes, for how many years? } \\
\text { - If a "golden rule" exists, how does this influence (or } \\
\text { compromise) the decisions on public investments in your } \\
\text { community? }\end{array}$ & $\begin{array}{l}\text { It is imperative that the national legislation should not } \\
\text { impose a rule on SNG without imposing the corresponding } \\
\text { rule on the CG as well. If SNG are subject to a balanced } \\
\text { budget rule ("golden" or other), then the CG must ensure that } \\
\text { the SNG have access to revenues (local taxation, revenue } \\
\text { sharing, grants etc.) that are regular, predictable, and } \\
\text { proportional to their needs. The CG should also guarantee } \\
\text { that credit facilities exempting the beneficiary SNG from the } \\
\text { duty of interest payment, are not cancelled before the end of } \\
\text { the debt repayment period. }\end{array}$ \\
\hline 6 & \multicolumn{2}{|c|}{ Is there any conceptual link between borrowing, debt management and capital expenditures? } \\
\hline & $\begin{array}{l}\text { - What is the role of amortisation / depreciation as a link } \\
\text { between investments and debt? } \\
\text { - Is there a link between depreciation of the asset in the } \\
\text { books and the annual amortisation of the local public } \\
\text { debt? }\end{array}$ & $\begin{array}{l}\text { The SNG should define the debt repayment schedule on the } \\
\text { basis of the useful life of the asset financed through } \\
\text { borrowing, in order to ensure that the pay-as-you-use } \\
\text { principle is respected. The depreciation of the asset should } \\
\text { follow the same pace. }\end{array}$ \\
\hline 7 & \multicolumn{2}{|l|}{ What is the depreciation policy at the local level? } \\
\hline & $\begin{array}{l}\text { - Systems of depreciation } \\
\text { - Rates of depreciation }\end{array}$ & $\begin{array}{l}\text { The depreciation should be linear on the replacement value. } \\
\text { The rate should be defined as a function of the expected } \\
\text { useful life of the asset. }\end{array}$ \\
\hline 8 & \multicolumn{2}{|c|}{ How is the local public debt defined? (gross vs. net public debt) } \\
\hline & $\begin{array}{l}\text { Does a concept of "gross public debt minus capital = net } \\
\text { public debt" exist? } \\
\text { Do such borrowing limits exist? If yes, which ones? }\end{array}$ & $\begin{array}{l}\text { The concepts of gross and net public debt are important } \\
\text { when borrowing is constrained by institutional limits. }\end{array}$ \\
\hline \multirow[t]{2}{*}{9} & \multicolumn{2}{|l|}{ Are the rules concerning borrowing and debt identical... } \\
\hline & $\begin{array}{l}\text { - ...for the local and regional level of government? } \\
\text { - ...for the regional and central level of government? }\end{array}$ & $\begin{array}{l}\text { The political autonomy of SNG may run against the } \\
\text { regulation of budgeting and borrowing at the central level. }\end{array}$ \\
\hline
\end{tabular}




$$
\Delta I=\Delta B=\frac{S-(D+P)}{r+m} \times 100
$$

where

$$
\begin{aligned}
& \Delta I \text { marginal investment } \\
& \Delta B \quad \text { marginal borrowing }
\end{aligned}
$$

$S \quad$ net savings on the current account (according to the European System of Accounts [ESA 95], this is the primary balance minus interest payments and amortisation of the existing debt)

$D \quad$ operating expenditures related to the new asset created by $\Delta \mathrm{I}$

$P \quad$ operating expenditures related to the local public service that $\Delta \mathrm{I}$ allows to offer

$r \quad$ interest rate for $\Delta \mathrm{B}(\%)$

$m$ depreciation rate of $\Delta \mathrm{I}=$ amortisation rate of $\Delta \mathrm{B}(\%)$, according to the pay-as-you-use principle (e.g. if the useful life of $\Delta \mathrm{I}$ is 20 years, then $\mathrm{m}=5$

What does this formula tell us? First, it tells that the costs incurred by earlier investments cannot be left out of consideration: $S$ is the net saving after deduction of the financial costs of the existing stock of capital and the related debt (i.e. interest and amortisation). Second, it shows that $\Delta B$ brings about additional financial costs $(r+m)$ that must be included in the current account. If both $D$ and $P$ are zero, then $\Delta B$ is equal to $100 \mathrm{x} S /(r+m)$. If $S$ is given the value of $100^{\prime} 000$ euro for example, with $\mathrm{r}=5$ and $\mathrm{m}=5$ (20 years), then the local government can envisage to incur new debt $(\Delta B)$ up to the limit of 1'000'000 euro. However, if the new investment $\Delta I$ generates some operating costs and allows to provide additional units of public service, then $D$ and $P$ must also be taken into consideration: in the future budget, these costs would reduce $S$, thus the residual capacity to pay for $r$ and $m$. Take the example of a new cultural centre $(\Delta I)$. The net surplus of the current account $(S)$ should be sufficient to cover the annual interest


energy, insurances etc. $(D)$, as well as the new current expenditures related to the cultural events offered in the building, minus entrance fees and revenues from sponsors (if any) $(P)$.

Figure 2 illustrates the mechanisms by which individual investment decisions get embedded in the local budget and changes in the budget lead to further investment. It is a simple circuit of local public finance with two possible entry points.

The first entry point is a well-defined investment project $(\Delta I)$ which figures on the list of priorities in the strategic plan of the local government. It may be, for instance, the renewal of the secondary school building, maintenance and reparation works on the road leading to the local industrial park, or the construction of new theatre or cultural centre. The investment is financed from equity capital or borrowing, or from development grants and other current revenues (suboptimal solution), or from a combination of these. In any case, the local government will need to take into consideration the future operation and maintenance costs related to the asset $(D)$, though this is normally compensated by user charges and fees and may be further mitigated by potential economies of scale derived from the investment. It also needs to consider the costs of the local public service provided through the new asset $(P)$. Finally, 
Figure 2 The circuit of sound investment management at local governments

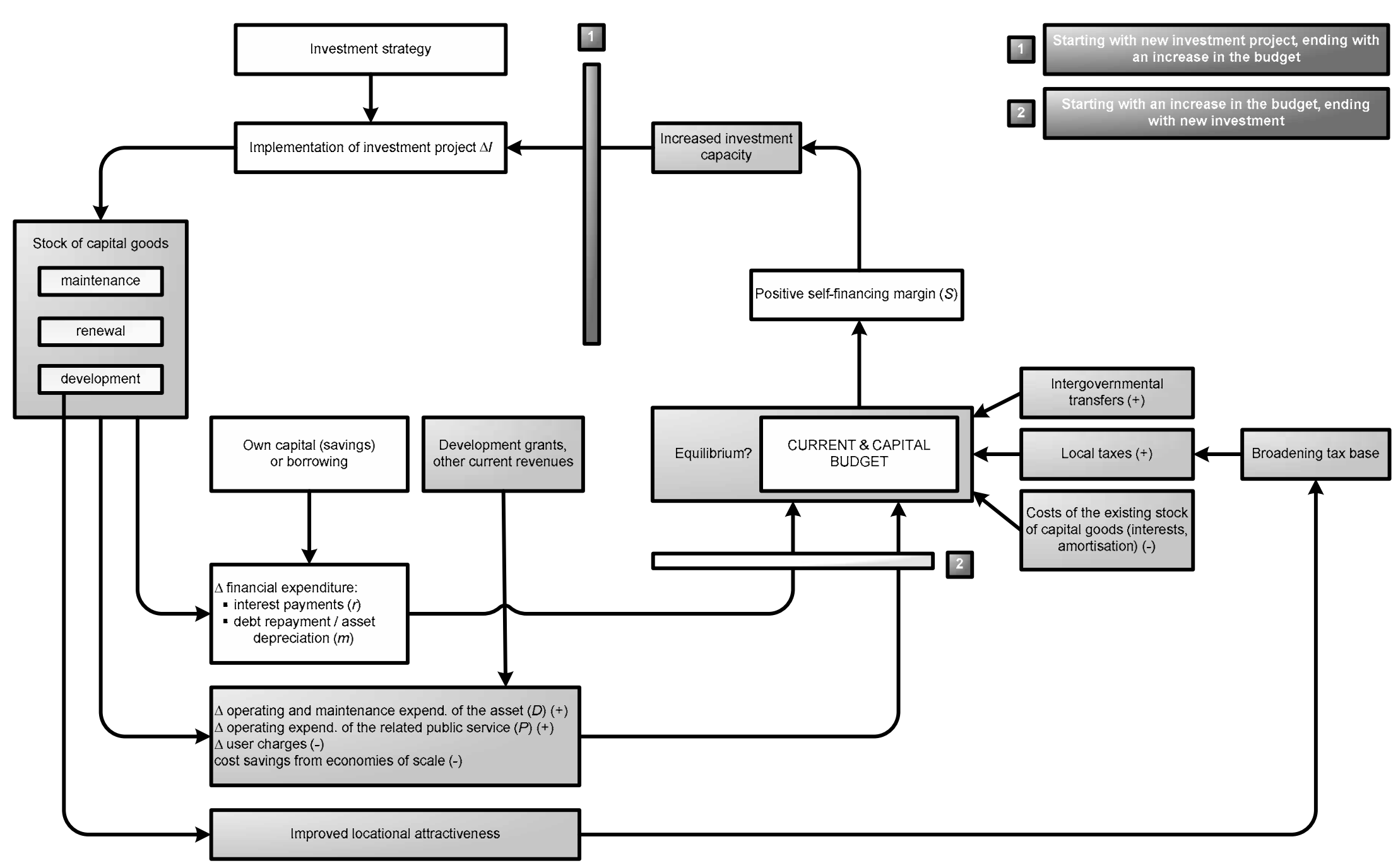

Source: Dafflon (2005) 
if own capital or debt $(\Delta B)$ are involved in the funding scheme, the local government must also calculate with the financial costs of debt service (interest payment $\left[\begin{array}{lll}r & x & \Delta B\end{array}\right]$, debt amortisation and the depreciation of the asset $\left[\begin{array}{lll}m & x & \Delta B\end{array}\right]$ ). All these cost items affect the budget of the local government in which, if a balanced budget rule is imposed by the law, revenues and expenditures (current, or current and capital) are to be kept in balance by the end of the fiscal year. The only variables by which the local government can adjust the budget to reach a balance, are local taxation and, to a lesser extent, intergovernmental transfers.

While all three types of investment - renewal, maintenance, and development - increase the financial and operating expenditures of the community, the third type, development (i.e. the construction of new facilities) also enhances the attractiveness of the local government for citizens and businesses. This is likely to trigger an inflow of new taxpayers in the jurisdiction, which broadens the local tax base and thereby leads to an increase in the revenues from local taxes, user charges and fees. Together with the intergovernmental transfers and the "inherited" stock of capital goods (minus related financial and operating expenditures), this new tax yield boosts the local government budget. The impact of renewal or maintenance of an existing asset is usually much weaker, except if these efforts lead to a substantial improvement in the physical condition of the asset, that is, if the asset was extremely depleted prior to the spending operation. The potential tax base effect is one reason why local policymakers prefer new developments in the sphere of voluntary functions, rather than renewal and maintenance works in the fields of mandatory responsibilities. However, the vertical order of maintenance, renewal and development in the box "stock of capital goods" is not accidental. Budget responsibility implies, namely, that the local government should first maintain its existing productive capital. Second, before deciding about the renewal of an asset, it should analyse whether there is a continuing demand for the asset or whether changing local conditions (community preferences etc.) have made it needless. Development is a third priority and should only be undertaken if, after the necessary maintenance and renewal of the existing capital, the investment capacity has not yet been fully utilised.

The second entry point to the circuit is marked by an increase of the available resources in the local budget. This may result from a rise in intergovernmental transfers, shared revenues and grants, a boost in local tax revenues (incl. user charges, fees) due to a larger tax base, higher tax rates or a more efficient tax administration, or from an increase in the stock of capital goods. If the current (or overall, depending on the actual balanced budget rule) budget is not only in equilibrium but provides even a small structural surplus, then the local government may realise what we call here a positive self-financing margin (Dafflon 1998: $219 \mathrm{ff}$.). This means that the local government has an increased financial capacity compared to the previous period, which allows it to consider embarking on another expenditure programmes, including investments. In short, the self-financing margin is a measure of the disposable residual income of a local government, the money which is left at the end of the fiscal year for serving other purposes.

It is important to note that the self-financing margin we are proposing here as an indicator of capacity is not equivalent to the surplus of the overall budget. Rather, it is derived from the actual balance and is a result of a series of accounting operations. In order to calculate the structural self-financing margin on the basis of the surplus figure, the latter has to be adjusted for extraordinary expenditures and revenues, the consolidation of internal accounts, the amortisation in the books and the operations affecting the internal reserves. The self-financing margin is thus a kind 
of a financial result of the fiscal year, but also a planning tool insofar as it allows to foresee the feasibility of future expenditure decisions. The constituency of the local government can decide about how this margin is going to be used. Whatever the result of the decision (a cut in local tax rates, a new investment project, a new spending programme in social affairs or education etc.), however, the projections must take into account the mid-term financing need of the planned operation. Therefore, the principle of financial prudence requires that, in a last step of calculation, all irregular revenue and expenditure items (or items that are subject to strong cyclical fluctuations) be left out of consideration. This final operation leads to the net self-financing margin of the local government which is an even more refined and thus more reliable capacity measure.

\section{Managing Local Public Debt: An Issue of Self-Control?}

The aim of this brief study was to show that managing local public debt is not so much an issue of fiscal capacity as an issue of self-control. Surely, the central government and the legislative have clear responsibility in stabilising the general macroeconomic conditions and creating an efficient intergovernmental fiscal framework that provides sufficient autonomy to lower levels and makes revenue flows transparent and predictable. On the other hand, regardless of the actual deficiencies in macroeconomic policy and intergovernmental institutions, subnational governments must make the greatest possible effort to preserve a sound fiscal management. The formal respect of the institutional rules on borrowing and debt is not sufficient. Subnational governments need to assume responsibility for their financial decisions not only towards the law but also towards their own taxpayers and those of other jurisdictions. Debt is therefore the optimal solution for funding local investments as it restores the coincidence between deciders, beneficiaries and taxpayers. However, debt finance also requires a prudent and proactive fiscal policy in which the costs and benefits are measured and compared individually for each investment project and the volume of investment is adjusted to the actual financial capacity. Considering the massive volume of necessary investments in the infrastructure and the tightness of fiscal resources at all levels of government, Central and East European transition countries have a particular interest in adopting budget responsibility as a leading management principle. 


\section{References}

Balás, G. and J. Hegedüs (2004). "Local Government Borrowing in Hungary." In: P. Swianiewicz (2004) (ed.), Local Government Borrowing: Risks and Rewards. A Report on Central and Eastern Europe. Budapest: OSI / LGI, pp. 79126.

Blažek, J., J. Přikryl and T. Nejdl (2003). "Capital Investment Funding in the Czech Repulic." In: K. Davey (ed.), Investing in Regional Development: Policies and Practices in EU Candidate Countries, Part II (Country Reports), Budapest: OSI / LGI, pp. 179-274.

Buchanan, J. M. and R. E. Wagner (1977). Democracy in Deficit: The Political Legacy of Lord Keynes. New York / San Francisco / London: Academic Press.

Coombs, H. M. and D. E. Jenkins (1994). Public Sector Financial Management. $2^{\text {nd }}$ edition, London: Chapman \& Hall.

Dafflon, B. (ed.) (2002). Local Public Finance in Europe: Balancing the Budget and Controlling Debt. Cheltenham: Edward Elgar.

Dafflon, B. (2005). Lectures on local public finance. Chapter 5 (mimeo). University of Fribourg, Switzerland.

DEXIA (2002). Local Finance in the Fifteen Countries of the European Union. Brussels / Paris: DEXIA.

Filas, J., T. Levitas and M. Piszczek (2002). "Local Government Budgeting - Poland." In: M. Högye (ed). Local Government Budgeting. Budapest: OSI / LGI, pp. 397-464.

Ghinea, A., G. Căluşeru, I. Nicola and S. Stretean (2004). "Bond Issues and Bank Loans: New Mechanisms to Support Local Development in Romania." In: P. Swianiewicz (ed). Local Government Borrowing: Risks and Rewards. A Report on Central and Eastern Europe. Budapest: OSI / LGI, pp. 277-318.

Gurraj, A., A. Hoxha, A. Pasha, G. Ruli, Q. Talka and I. Tanku (2002). "Local Government Budgeting - Albania." In: M. Högye (ed). Local Government Budgeting. Budapest: OSI / LGI, pp. 103-154.

Högye, M. (ed.) (2002). Local Government Budgeting. Budapest: OSI / LGI.

Jókay, Ch., G. Szepesi and Gy. Szmetana (2004). "Municipal Bankruptcy Framework and Debt Management Experiences 1996-2000." In: M. Kopányi, D. Wetzel and S. El Daher (eds), Intergovernmental Finance in Hungary: A Decade of Experience 1990-2000. Washington D. C. / Budapest: World Bank and OSI / LGI, pp. 593-616.

Kling, J. and V. Nižňanský (2004). "From Deregulation to Regulation and Stabilization in Slovakia." In: P. Swianiewicz (ed). Local Government Borrowing: Risks and Rewards. A Report on Central and Eastern Europe. Budapest: OSI / LGI, pp. 175-226.

Kopańska, A. and T. Levitas (2004). "The Regulation and Development of the Subsovereign Debt Market in Poland: 1993-2002." In: P. Swianiewicz (ed). Local Government Borrowing: Risks and Rewards. A Report on Central and Eastern Europe. Budapest: OSI / LGI, pp. 25-77.

Kopányi, M., S. El Daher, D. Wetzel, M. Noel and A. Papp (2004). "Modernizing the Subnational Government System." In: Kopányi, M., D. Wetzel and S. El Daher (eds), Intergovernmental Finance in Hungary: A Decade of Experience 1990-2000. Washington D. C. / Budapest: World Bank and OSI / LGI, pp. 15-75.

Musgrave, R. A. (1963). "Should We Have a Capital Budget?", Review of Economics and Statistics, 45 (2), pp. 134137. 
Novaresi, N. (2001). Discipline budgétaire: Étude de l'influence du referendum financier et des règles d'équilibre budgétaire sur les finances publiques des vingt-six cantons suisses. Doctoral thesis, University of Fribourg, Switzerland. Fribourg: BENEFRI Centre d'études en économie du secteur public.

Ott, K. and A. Bajo (2002). "Local Government Budgeting - Croatia." In: M. Högye (ed). Local Government Budgeting. Budapest: OSI / LGI, pp. 215-272.

Pujol, F. (2000). L'incidence des preferences sur la discipline budgétaire. Doctoral thesis (mimeo), University of Geneva, Switzerland.

Rattsø, J. (2002). "Fiscal Controls in Europe: A Summary." In: B. Dafflon (ed.) (2002). Local Public Finance in Europe: Balancing the Budget and Controlling Debt. Cheltenham: Edward Elgar, pp. 277-290.

Rossi, S. and B. Dafflon (2002). "The Theory of Subnational Balanced Budget and Debt Control." In: B. Dafflon (ed.) (2002). Local Public Finance in Europe: Balancing the Budget and Controlling Debt. Cheltenham: Edward Elgar, pp. 15-44.

Roubini, N. (1995). The Economics of Fiscal Bondage: The Balanced Budget Amendment and Other Binding Fiscal Rules. New York Stern School of Business, mimeo.

Sootla, G., A. Jaansoo, P. Tammert, D. Ainsoo, E. Pedastsaar, T. Tüür, T. Milt and A. Surva (2002). "Local Government Budgeting - Estonia." In: M. Högye (ed). Local Government Budgeting. Budapest: OSI / LGI, pp. $273-$ 328 .

Swianiewicz, P. (2004a) (ed). Local Government Borrowing: Risks and Rewards. A Report on Central and Eastern Europe. Budapest: OSI / LGI.

Swianiewicz, P. (2004b). "The Theory of Local Borrowing and the West-European Experience." In: P. Swianiewicz (ed). Local Government Borrowing: Risks and Rewards. A Report on Central and Eastern Europe. Budapest: OSI / LGI, pp. 5-23.

Swianiewicz, P. (2004c). "Comparing International Experiences: Emerging Markets of Local Borrowing?" In: P. Swianiewicz (ed). Local Government Borrowing: Risks and Rewards. A Report on Central and Eastern Europe. Budapest: OSI / LGI, pp. 385-422.

Tchavdarova, G., S. Ivanov and E. Savov (2002). "Local Government Budgeting - Bulgaria." In: M. Högye (ed). Local Government Budgeting. Budapest: OSI / LGI, pp. 155-214.

Ter-Minassian, T. and J. Craig (1997). "Control of Subnational Government Borrowing", in T. Ter-Minassian (ed.) Fiscal Federalism in Theory and Practice. Washington D. C.: International Monetary Fund, pp. 156-172.

Wetzel, D. (2001). Decentralization in the Transition Economies: Challenges and the Road Ahead. Washington D. C.: The World Bank. 